\title{
LIMBAJUL ȘI TERMINOLOGIA EDUCAȚIEI LITERAR-ARTISTICE
}

\author{
VLAD PÂSLARU \\ Institutul de Filologie Română „B. P.-Hasdeu” al MEC
}

\begin{abstract}
Rezumat. Autorul definește limbajul educației literar-artistice (formării cititorului de literatură) și terminologia acesteia, pe care o structurează ierarhic pornind de la principiile generale ale cunoașterii și concretizând-o in baza principiilor educației artistic-estetice și educației literar-artistice. Astfel abordată și structurată, se conturează și principiile de integralizare a terminologiei educației literar-artistice, oferind cititorului repere fezabile de cunoaștere, proiectare și tehnologizare a procesului de formare a cititorului de literatură.

Cuvinte-cheie: limbaj al educației literar-artistice, integralizarea terminologiei educației literar-artistice, limbaj pedagogic, structurarea terminologiei educației literar-artistice, terminologia educației literar-artistice.
\end{abstract}

Abstract. The author defines the language of literary-artistic education (training of the literature reader) and its terminology, which he structures hierarchically starting from the general principles of knowledge and concretizing it based on the principles of artistic-aesthetic education and literary-artistic education. Thus approached and structured, the principles of integrating the terminology of literary-artistic education are outlined, offering the reader feasible landmarks of knowledge, design and technologicalization of the literature reader training process.

Keywords: language of literary-artistic education, integration of the terminology of literary-artistic education, pedagogical language, structuring of the terminology of literary-artistic education, terminology of literary-artistic education.

Abrevieri: ELA - educaţie literar-artistică; DEX-09 - Dicționarul explicativ al limbii române, 2009; MDA2-2010 - Marele dicționar academic, 2010; DEX-98 - Dicționarul explicativ al limbii române, 1998; DTL-1998 - Dicționarul de termeni lingvistici, 1998; NODEX-2002 - Noul dicționar explicativ al limbii române, 2002; DN-86 - Dicționar de neologisme, F. Marcu; MDN-2000 - Marele dicționar de neologisme; DLRLC-1955-1957, D. Macrea; Dicționarul limbii române literare contemporane; Sinonime-2002 - Dicționar de sinonime, 2002; Sinonime82 - Dicționar de sinonime, 1982; Şăineanu-1929 Dicționarul universal al limbii române, L. Șăineanu; DEX-S-1988 - Supliment la Dicționarul explicativ al limbii române, 1988.

Limbajele sunt definitorii cunoașterii-formării-dezvoltării umane obiectele principale ale educației, studiate-proiectate-realizate de pedagogie. 
Caracterul lor definitoriu decurge din capacitatea cuvântului de a exprima sensuri și simboluri, acestea, la rândul lor, fiind definitorii comunicării umane. Cunoașterea însăși este comunicare - cu lumea din exterior și cu propriul univers intim - și comunicarea este cunoaștere, o cunoaștere cu o conotație uzuală, dar totuși cunoaștere în esență. Și formarea-dezvoltarea ființei umane este, în mare, o activitate de cunoaștere și desăvârșire. Atât cunoașterea, cât și comunicarea-formarea-dezvoltarea (de capacităţi de personalitate), operează cu anumite coduri, cunoscute și cu numele de limbaje. Deoarece cunoașterea, educația și chiar întreaga existență umană se manifestă hic et nunc, adică într-un timp și spațiu concrete, și cea de-a treia dimensiune a acestora, modalitatea, este întotdeauna concretă. Respectiv, orice operație-acțiune conștientă a omului - conștiința fiindu-i dată prin limbă, necesită și se produce efectiv într-un anumit tip de limbaj. Prin urmare, tipurile de limbaje își au originea în tipurile de cunoaștere, înțeleasă la cel mai înalt grad de generalitate.

Sunt cunoscute patru tipuri generale de cunoaștere: empirică, miticreligioasă, artistic-estetică și științifică. Fiecare tip de cunoaștere operează într-un limbaj specific: uzual, religios sau spiritual, artistic-estetic, științific. Pe măsura diversificării și concretizării tipurilor de cunoaștere se stabilesc noi categorii de limbaje. Astfel, limbajul educației literar-artistice este dedus din limbajul pedagogic și limbajul artistic-estetic, iar acestea din urmă, din toate cele patru tipuri generale de limbaje. Pe linia concretizării, limbajul ELA include un limbaj al literaturii (limbajul poetic), un limbaj estetic, unul teoretic-literar și unul istoric-literar, precum și un limbaj al eticului și moralei; un limbaj al pedagogului și unul al elevului; un limbaj al lecturii expresive și un limbaj al comentării/interpretării operelor și fenomenelor literare - limbajul hermeneuticii literare, etc.

Se stabilește astfel că natura limbajelor este funcție a tipului de activitate umană, respectiv, a tipului de cunoaștere.

În timp ce celelalte științe despre om doar îl studiază și-1 prezintă pe acesta ca pe un obiect științific, pedagogia este unica știință (cu excepția filosofiei, care este mai întâi mod de gândire, apoi și știință) care sintetizează cele trei dimensiuni fundamentale ale cunoașterii omului: epistemică, teoretică și tehnologică - descoperă legile și principiile devenirii depline a omului în calitatea sa de ființă umană; stabilește condițiile spațio-temporale (hic et nunc) și modale de formare a sa ca om în cadrele familial, etnic și social; elaborează metodologiile de dezvoltare a personalităţii sale. In senso latu, educaţia se identifică cu cunoașterea, iar pedagogia, care o studiază-conceptualizeazăproiectează-realizează, poate pretinde că deține cel mai valoros și mai sofisticat limbaj, redat de o terminologie pe măsură.

Limbajul ELA. Dicționarele explicative definesc limbajul drept:

- sistem de comunicare alcătuit din sunete articulate, specific oamenilor, prin care aceștia își exprimă gândurile, sentimentele și dorințele; limbă, grai (DEX-09; MDA2-2010; DEX-98; DTL-1998); 
- proces de comunicarelexpunere (DLRLC-1955-1957; DN-86; MDN-2000);

- facultate/capacitate de exprimarelexpunere (NODEX-2002);

- grai, limbă, vorbire (Sinonime-2002; Sinonime82; Șăineanu-1929);

- sistem de caractere și simboluri (folosit în programare)(DEX-S-1988).

Nici una din definițiile date limbajului nu este (nu poate fi) exhaustivă, dar cele cinci tipuri de determinative sugerează formula celei mai complete definiții a limbajului, din care se desprinde limbajul pedagogic ca limbaj profesional. Cu mențiunea de rigoare însă că nu limbajul didactic este primar față de cel pedagogic, precum indică DTL-1998, ci invers, limbajul pedagogic este generic, didactica fiind doar una din științele particulare ale pedagogiei. $\mathrm{Cu}$ atât mai mult între limbajul didactic și cel pedagogic nu se stabilește un raport de sinonimie, ci unul de ierarhie.

Dedus din definitiiile generale ale limbajului, limbajul pedagogic este unul profesional, care include specificații pe domeniile acreditate științific.

Educația literar-artistică, recunoscută la finele sec. al XX-lea drept domeniu distinct al pedagogiei (Совершенствование, 1979; Pâslaru, 5; Pâslaru, 4; Pâslaru, 3), este componenta disciplinară a cunoașterii artistic-estetice (Pâslaru, 3) și a educației artistic-estetice, alături de educația muzicală, educația artistic-plastică, educația coregrafică, educația teatrală etc. Respectiv, ELA și-a stabilit un limbaj şi o terminologie specifice, care reprezintă cele trei dimensiuni ale cunoașterii/cunoașterii literar-artistice.

Limbajul ELA este reprezentat de totalitatea resurselor comunicativlingvistice, verbale și nonverbale, necesare proiectării și realizării activitătiii literare-lectorale a educabililor, precum și studiului și cercetării elevilor cititori, a cadrelor didactice, a altor subiecți antrenați în procesul ELA, a curriculumului ELA, a procesului de educaţie literar-artistică, a metaeducaţiei literare etc. Fiecare unitate de limbaj este obiectivată de un termen: cultură literară-lectorală, curriculum, lectură, elev cititor, lector, mimică, gestică, receptare literară, stare de lectură etc.

Structural, limbajul ELA se constituie din limbajul poetic, limbajul științific (estetic, teoretic-literar, istoric-literar, limbajul lecturii, limbajul pedagogic propriu-zis), limbajele facial și gestual. În limbajul teatral, aferent limbajului ELA, funcționează limbajele corporal și scenic. Toate tipurile de limbaje aferente ELA interacționează, creând produse ale cunoașterii literar-artistice, științifice și pedagogice. Examinarea separată a acestora (în mediul neprofesional) produce confuzii, care trădează o cunoaștere incompletă, parțială, precum în exemplul de mai jos.

${ }^{1}$ Teoria educației literar-artistice a fost confirmată de comunitatea științifică prin conferirea autorului a titlului doctor habilitat în pedagogie, la 21 septembrie 1998, iar pe plan mondial - prin publicația "The Theory of Artistic-Aesthetic Education versus Didactics Arts" (Pâslaru, 3). 
Povestea lui I. Creangă Fata babei și fata moșneagului are un mesaj deschis, chiar simplist, construit pe principiul bine faci-bine găsești sau după faptă și răsplată, mesaj accesibil chiar și preșcolarilor. Există însă în poveste o frază care depășește acest mesaj, cei mai mulți elevi (Pâslaru, 4, p. 158, 162, 168-169), ba chiar și profesori de limba și literatura română nefiind în stare să-i explice sensul, deoarece nu cunosc suficient de bine sensul expresiei populare a increți din sprincene (limbajul facial) și semnificația personajului-simbol în creația populară orală românească Sfânta Duminică (limbajul artistic) și formele de exprimare a atitudinii autorului în operele literare (limbajele estetic, teoretic-literar, al lecturii):

„... sfânta Duminică cam încrețește din sprincene, dar n-are încotro. Ci binecuvântează pe fată..." (Creangă, p. 100).

Elementul limbajului facial a încreți din sprincene exprimă o stare de nemulțumire, supărare chiar; Sfânta Duminică este simbolul justiției supreme - a justiției dumnezeiești; expresia n-are incotro sugerează atotputernicia lui Dumnezeu, pe care nu o poate neglija nici chiar Sfânta Duminică, ea fiind obligată să instituie dreptatea în familia celor patru personaje. Dar chiar și cunoscând bine aceste lucruri, nu este clar, de ce Sfânta Duminică „cam încrețește din sprincene” - adică nu-i place alegerea fetei moșneagului, care a optat pentru „,ea mai veche și mai urâtă” dintre lăzi, doar fata a meritat din plin plata pentru toate faptele bune săvârșite și pentru munca prestată în folosul Sfintei Duminici, ca și pentru calitățile sale morale?

Răspunsul se găsește în întreaga creație crengiană, dar și în conștiința populară, și este certificat de expresii precum până ajungi la Dumnezeu te mănâncă sfinții sau $<$ Dănilă $>$, ,.. tot mai mult se bizuia pe drughineață decât in sfânta cruce" (Creangă, p. 27), care reprezintă și poziția autorului față de justiţia divină. Fraza cu pricina este anume a lui Ion Creangă, el a făcut-o pe Sfânta Duminică să-i pară rău/să fie invidioasă, astfel desacralizând-o și sugerând cititorului că narațiunea sa nu-i decât ... o poveste!, în viaţa reală lucrurile fiind deseori inverse: în cine trage, în acela se și bate etc.

Totuşi I. Creangă a scris povestea, deci a urmat logica (principiile) artei, construind o lume imaginară, în care totul este posibil - posibilul fiind obiectivat de idealul uman pentru o viață mai bună și starea de bine, obținute pe dreptate și de Dumnezeu protejate.

Prin urmare, cunoașterea limbajelor aferente ELA și a modului în care acestea interacționează în opera literară sunt condiția sine qua non a unei receptări cât mai depline, respectiv, a dezvoltării literar-artistice a cititorului.

Pe coordonata epistemică a ELA au fost identificați termeni precum: absolutul, Adevărul, autoreflexie, Binele, conștiință, conștiință artistică, cunoaștere, cunoaștere artistic-estetică, cunoaștere empirică, existență metafizică, cunoaștere mitic-religioasă, cunoaștere știinţifică, Dreptatea, ființă umană, Frumosul, humanitas, identitate umană, Libertatea, obiect al 
cunoașterii, reflexie, subiect al cunoașterii, suprasensibil, tipuri de cunoaștere, valori artistice, valori fundamentale ale omenirii, valori literar-artistice etc.

Epistemele Adevărul, Binele, Frumosul,Dreptatea, Libertatea, cunoscute și ca valori fundamentale ale omenirii (Surdu), conștiințăa, conștiință artistică, identitate umană, valori artistice, valori literar-artistice indică nucleul tare ${ }^{2}$ al conceptului teleologic (scop-obiective-finalități) al ELA: indiferent de tipul și treapta de învățământ, din acestea se vor dezvolta valorile ELA ce urmează a fi/sunt deduse/elaborate/formate educabililor.

Termenii absolutul, existență metafizică, ființă umană, humanitas, suprasensibil denumesc epistemele existenței umane. Acestea pot fi abordate începând cu treapta liceală și până la cea de studii doctorale (continuând apoi pe parcursul activității profesionale întreaga viață).

Autoreflexia și reflexia sunt termenii-cheie ai activității de cunoaștere. Se specifică preponderența reflexiei în cunoașterea empirică și cea științifică (tipuri de cunoaștere determinative, proprii cunoașterii existenței fizice), având orientare de la subiectul cunoașterii către un obiect al cunoașterii aflat în afara sinelui (universului intim), și preponderența autoreflexiei în cunoașterea mitic-religioasă și cea artistic-estetică (incluzând cunoașterea literar-artistică) ca tipuri de cunoaștere autoreflexive, proprii existenței metafizice - orientate de la subiectul cunoașterii către sine însuși, către universul intim ${ }^{3}$ al subiectului cunoașterii.

Deoarece educația/educația literar-artistică se identifică cu cunoașterea/ cunoașterea literar-artistică, câmpul semantic construit de termenii cunoaștere, cunoaşterea artistic-estetică, cunoaștere empirică, cunoaștere miticreligioasă, cunoaștere științifică, obiect al cunoașterii, subiect al cunoaşterii, tipuri de cunoaștere marchează domeniile aferente ELA. Acestea ar trebui deci să penetreze teleologia și conținuturile ELA pe tot parcursul școlar, de la educația preșcolară la studiul literaturii la facultate.

Coordonata teoretică este reprezentată de termenii: activitate de lectură, activitate literară, calitatea educației/educației literar-artistice, caracter național, caracter obiectiv, caracter subiectiv, cititor de literatură/lector, competență, competență comunicativ-lingvistică, competență literar-lectorală, conținuturile ELA, creație literară, cultură literară-lectorală, educație literarălectorală, elev cititor, emoții estetice, epistemologia ELA, finalitate a ELA, gândire artistică, ideal artistic, imaginație artistică, lectură, metodologiile ELA (metode-procedee/tehnici-forme-mijloace), negocierea sensurilor, principiile ELA, operă literară, receptare literară, stare de lectură, student cititor, teleologia ELA, text literar, trăiri estetice, valoarea imanentă a operei

2 În pedagogia contemporană prin sintagma nucleu tare este denumită matricea unui domeniu/aspect al educației, care are caracter prescriptiv pentru proiectareatehnologizarea acestuia.

Termen folosit în limba rusă prin sintagma внутренний мир человека şi tradus o vreme ad litteram, deci inadecvat, în arealul pruto-nistrean prin lumea interioară a omului. 
literare, valoarea in actu a operei literare, valori ale cititorului, valori estetice, valori morale, valori religioase, valori teoretice etc.

În abordare curriculară $\breve{4}^{4}$ termenii angajaţi pe coordonata teoretică se distribuie în domeniile conceptual, teleologic, conţinutal și metodologic.

Componenta conceptuală stabilește/prescrie epistemele pentru fiecare din cele trei componente următoare ale curriculumului, utilizând termenii: calitatea educației/educației literar-artistice, caracter național, caracter obiectiv, caracter subiectiv, educație literară-lectorală, epistemologia ELA, principiile ELA, valoarea imanentă a operei literare, valoarea in actu a operei literare, valori ale cititorului, valori estetice, valori morale, valori religioase, valori teoretice.

Componenta teleologică a teoriei ELA este acreditată de termenii: scopul ELA, obiectivele ELA (obiective cadru, obiective de referință, obiective operaționale) cititor de literaturăllector, competență, competență comunicativ-lingvisticăa, competență literar-lectorală, cultură literarălectorală, elev cititor, emoții estetice, finalitate a ELA, ideal artistic, student cititor, teleologia ELA, trăiri estetice.

Componenta conținutală este reglementată de termenii: conținuturile ELA, estetica literaturii, istoria literaturii, operă literară, pedagogia artei, pedagogia lecturii, teoria literară, text literar.

Componenta metodologică a teoriei ELA reprezintă coordonata modală a educației, răspunde la întrebarea cum trebuie proiectată-realizată ELA și este identificată de termenii: activitate de lectură, activitate literară, creație literară, gândire artistică, imaginație artistică, lectură, metode-procedeel tehnici-forme-mijloace, metodologiile ELA, negocierea sensurilor, receptare literară, stare de lectură.

Pe coordonata metodologică (sau tehnologică) ELA este realizată prin termenii: activitatea elevului, activitatea literară-lectorală a elevului, activitatea profesorului, analiza literară, comentariul literar, curriculumul ELA, hermeneutica literară, formele lecturii, metode ale ELA, metodele ELA, mijloace ale ELA, obiectivele ELA (drept componente ale proiectării metodologice a ELA), procedeele ELA, stadiile lecturii etc.

Terminologia ELA nu se reduce la registrul de termeni de mai sus, dar aceștia reprezintă osatura cunoașterii literare, formării și dezvoltării literarelectorale a educabilului. În plan epistemic și teoretic, terminologia ELA poate antrena întreaga terminologie a filosofiei artei, esteticii/esteticii literare, psihologiei artei, teoriei literare ș.a. (la cele trei trepte ale învățământului universitar), un compendiu motivat pedagogic al acesteia (treptele gimnazială și liceală), sau să nu fie operată efectiv, dar să fie reprezentată de activități

${ }^{4}$ Curriculumul este definit de Comisia Europeană pentru Educație drept totalitate a acțiunilor educative (Crișan), deci în contextul examinat în acest text curriculumul nu este doar un document normativ pentru disciplina şcolară, ci un concept educațional general, care marchează întregul învățământul în societatea contemporană. 
propedeutice în scopul unor viitoare abordări teoretice (treptele educației preșcolare și a învățământului primar).

În concluzie. Limbajul ELA definește întreaga totalitate a fenomenelor și activităţilor în domeniu, este reprezentat lingvistic de terminologia ELA, dar nu se identifică cu aceasta, ci o relaționează conform principiilor specifice creației, receptării, cunoașterii și formării-dezvoltării literare-lectorale a individului uman. Limbajul ELA este fenomen al cunoașterii, formării și dezvoltării literar-artistice, dar și obiect de exegeză științifică și de cunoaștere teoretic-aplicativă a subiectului cunoscător/subiectului educabil. La orice treaptă de învățământ s-ar aplica, terminologia ELA trebuie să descindă din principiile cele mai generale ale cunoașterii/cunoașterii artistic-estetice către cele de tehnologizare a procesului educațional.

\section{Referințe bibliografice:}

1. Creangă, Ion. Opere. Ediție de Iorgu Iordan și Elisabeta Brâncuși. București: Editura Fundației Culturale Române, 1993.

2. Crişan, Al. Literatura naţională şi limba maternă în învăţământul liceal european. În: Limba română, 1996, nr. 5-6, p. 47-55.

3. Pâslaru, Vlad. The Theory of Artistic-Aesthetic Education versus Didactics Arts. În: Handbook of Research on Applied Learning Theory and Design in Modern Education. Vol. I. Information Science Reference, Pensilvanya (USA): IGI Global, 2016, p. 65-92.

4. Pâslaru, Vlad. Introducere în teoria educației literar-artistice. București: Ed. Sigma, 2013.

5. Pâslaru, Vl. Concepţia educaţiei lingvistice şi literare. În: Limba română, 1995, nr. 5, p. 126-129.

6. Surdu, Al. Pentamorfoza artei. București: Editura Academiei Române, 1993.

7. Совершенствование литературного развития икольника. Сб. науч. трудов/НИИ ХВ АПН СССР; ред. Н. Кушаев. Москва, 1979.

Notă: Articolul a fost realizat în cadrul proiectului de cercetare 20.80009.1606.01 Valorificarea științifică a patrimoniului lingvistic național în contextul integrării europene, Institutul de Filologie Română „B. P.-Hasdeu” al MEC. 